\title{
The Use of Different Spelling Strategies among EFL Young Learners
}

\author{
SASAn BAleghizAdeH ANd ZeINAB Dargahi \\ Shahid Beheshti University, G.C., Evin, Tehran, Iran
}

Received: 12 February 2010 / Accepted: 23 September 2010

ISSN: $1697-7467$

\begin{abstract}
The present study aimed to investigate the frequency of children's spelling strategy use in the primary levels of learning English. It also compared the use of these strategies in good and average spellers with those of poor spellers. The participants of this study were 32 Iranian children at the first stages of learning to spell rated as being either low, average, or above average spellers. The children were asked to spell 20 words in a dictation. They were observed while spelling and were asked about the strategy they used to spell each word immediately after spelling. The results showed that retrieval was the most frequently used strategy by the participants most frequently used by the participants followed by sounding out and analogy. Considering the use of strategies in good, average, and poor spellers, it was concluded that the most common strategies for spelling were used more often by good and average spellers and less often by poor spellers.
\end{abstract}

Keywords: analogy, children, retrieval, spelling strategies

El uso de diferentes estrategias ortográficas entre jóvenes estudiantes de inglés como lengua extranjera

RESUMEN: Este trabajo tiene como objetivo investigar la frecuencia en el uso de estrategias ortográficas de los niños en los primeros niveles del aprendizaje del inglés. También se compara el uso de estas estrategias entre alumnos que escriben bien y normal con los que obtenían pobres resultados. Los participantes de este estudio fueron 32 niños iraníes en los primeras etapas de aprendizaje de la escritura que han sido clasificados en buenos, regulares y pobres atendiendo a su ortografía. Se pidió a los estudiantes que escribieran 20 palabras en un dictado. Se les observó mientras las escribían y se les preguntó sobre las estrategia que empleaban inmediatamente después de escribir cada palabra. Los resultados muestran que la recuperación fue la estrategia que más empleaban seguida de la pronunciación y la analogía. Considerando el uso de las estrategias por parte de los tres grupos, los que escriben bien, normal y mal, se puede concluir que las estrategias más comunes para escribir las empleaban con más frecuencia los que escribían bien y normal, y con menor frecuencia los que obtuvieron pobres resultados.

Palabras clave: analogía, recuperación, estrategias ortográficas 


\section{INTRODUCTION}

The process of spelling can be time consuming and tedious mostly when generating words which are too difficult. Students, especially children, may be distracted by the lack of spelling knowledge which inhibits their ability to write. There may be too much focus on spelling the words correctly while the generation of the text would be neglected. The act of composing is slowed and the train of thought is altered when one cannot spell a word correctly regardless of the extra tools used (Graham, 1999).

The main problem in most children classrooms is their inability to spell words correctly and this is due to the lack of useful spelling instructions based on solid research and development. Rote memorization tasks have frequently been used for spelling instruction. As a result, word spellings are often forgotten within days and are not applied to writing. This is not instruction based upon an understanding of spelling and the development of spelling skills. The problem is that there is a lack of research on how spelling actually develops and what cognitive processes are in use when one creates the spelling of a word (O'Sullivan, 2000).

It is argued that children use multiple strategies at any point in time of spelling (RittleJohnson \& Siegler, 1999). In addition, strategy use should be adaptive, i.e. dependent on the difficulty of the word being spelled. Previous research done on spelling strategies by RittleJohnson and Siegler (1999) verified that children use multiple strategies. They were not, however, able to directly address the adaptability and frequency of strategy use.

The present study explores children's spelling strategy use in the primary levels of learning English. It also aims to compare the use of these strategies in good and average spellers with those of poor spellers.

\section{LiteratURE REVIEW}

The definition of spelling is standard for most researchers, even for those in different theoretical camps. It is often viewed as simple letter-sound identification for young children who are learning to spell. But the basic question is how children spell and what strategies they use as they improve in spelling ability. This is where consensus among theorists breaks down.

Researches have shown that the development of new spelling skills emerges at different levels (Beers, 1980; Ehri, 1987; Ellis, 1993; Moats, 1995; Schlagal, 2001). For example, in the early stage of spelling, children spell words using alphabetic principles, but the next stages involve the use of some phonetic clues to spell. Each new stage is an improvement upon the last, meaning that the child's ability increases as s/he adds one new spelling strategy at a time; however, Moats (1995) cautions that not all children progress in the same way or at the same rate in the spelling process.

Stanovich and Cunnigham (1993) also demonstrated that spelling requires other cognitive domains in addition to alphabet knowledge such as larger spelling patterns and morphemes. They hypothesized that frequent exposure to print facilitates a developmental progression from alphabetic to spelling strategies. 


\subsection{Different types of spelling strategies}

There are many types of strategies used for spelling a word which have been reported in different studies. Retrieval is one of such strategies which, as the name suggests, is the direct recall of something. Simon and Simon (1973) described the generate-and-test strategy, which is writing a word that is unknown and examining it to see if it is spelled correctly. According to Simon and Simon, this is a strategy used by spellers who can visually recognize the correct spelling of the word. Graham (2000) describes the strategy of inventing spelling, which is using knowledge of phonemes to sound out words while spelling them. Using an analogy and sounding out the onset rhyme are other strategies children use (Graham, 1999; Greaney, 1997).

\subsection{Siegler's spelling development model}

The examination of children's strategy use while spelling is developed in Robert Siegler's model of spelling development (Chen \& Siegler, 2000; Crowley, Shrager, \& Siegler, 1997; Crowley \& Siegler, 1999; Shrager \& Siegler, 1998; Siegler, 1989, 1995, 1996, 2000, 2002; Thompson \& Siegler, 2000). Proponents of this theory posit that children use many different strategies to learn at any given time (Chen \& Siegler, 2000; Siegler, 1996; Siegler \& Crowley, 1991). The heart of the model rests on how learners choose one strategy over another. According to Siegler (1996), there are at least four ways in which change occurs in children's strategy use. One is the introduction of a better strategy or strategies. Another is the use of the known strategies which are more advanced. Third, a child could become more effective at using strategies. A fourth change in strategy use is that of a child choosing strategies based upon task requirements.

To the best of the researchers' knowledge,there is only one study which has used Siegler's spelling model to investigate spelling strategies in young learners who were learning to spell (Rittle-Johnson \& Siegler, 1999). Rittle-Johnson and Siegler (1999) examined spelling strategies longitudinally by looking at (a) the type of strategies used, (b) how effectively the strategies were applied, (c) what words were spelled correctly with which strategies, and (d) how long it took to apply the different strategies used. The findings of Rittle-Johnson and Siegler' (1999) study showed that their model appears to accurately represent children's development of spelling and they concluded that children used six different strategies to spell: (a) retrieval, (b) sounding out, (c) drawing analogies, (d) relying on rules, (e) visual memory, and (f) checking and syllabification. These strategies are defined in Table 1. They also found out that most of the children used more than one strategy to spell a word and seventy percent of them used a combination of various strategies.

The Rittle-Johnson and Siegler's (1999) intriguing study has provided new insight into development of spelling skills. It has also expanded our understanding of cognitive developments underlying spelling. The missing point, however, in their study is failure to take care of the use of spelling strategies in children who are good, average, and poor spellers. The frequency of children's strategy use was also not reported. Therefore, the present study aims at considering the frequency of different spelling strategies used by children at the beginning levels of learning how to spell and also compares the types of strategies used more frequently by good, average, and poor spellers. 


\section{Methodology}

\subsection{Participants}

The participants for this study were 32 true beginner learners, who were at the first stage of learning to spell, at the Iran Language Institute (ILI). These participants were children with the age range of 7 to 9 . They had learned the letters of the alphabet in their previous term and in the current term, had to deal with reading single words and spelling them correctly.

The teacher, who was the second researcher in the present study, rated students as low, average, or above average spellers. These ratings were based upon simple dictations and spelling tests. The majority of the students were considered as being «average» spellers.

\subsection{Material}

The words which the children were asked to spell were the ones included in their course book. By categorizing them, one can come to three groups of words: words with short vowels (e.g. bag), words with consonant digraphs (e.g. chair, sheep) and words with long vowels (e.g. bean, tray). Regardless of the children's spelling ability, all of them dealt with the same words. The words were presented to them based on the sequence of their appearance in their course book. At first, they learned easier words with short vowels, then they had the words with long vowels which included the five long vowels of /er /, /i:/, /ar /, /əu/ and /u:/.

\subsection{Procedure}

The children were asked to spell 20 words in a dictation. They were observed while spelling and immediately after the children spelled each word, they were asked to tell the second researcher which strategy they used to spell each word. This provided an immediate understanding of strategy use. Frequently, a video recording was made of the children for verification of reliability and validity. students:

The following scripted explanation and description of the spelling test was given to the

We are going to play a spelling game. Some of the words will be easy to spell and some of the words will be harder to spell. I want you to spell the words and after you spell a word, I'm going to ask you how you spelled it - how you knew the right way to spell it. You can do anything you want to spell the word. You might just spell the word, or you might sound out the word, or you might write the word a few ways and see which spelling looks right, or you might use another word you know how to spell to help you, or you might sound out part of a word and guess the rest. You can do anything else you want to spell.

After the instruction was given to the children, a set of words was read out to them. Then they were given a short time to spell each word and explain how they spelled it. Each word was read aloud once and repeated at the children's request. If a child did not start to write the word within five seconds, then the word would be repeated. When the children finished 
spelling each word, the second researcher said, "Okay, how did you know how to spell that word?» or «What did you do to spell that word?» The answers provided by the students were as follows:

«Teacher, I sounded it out. I wrote the letter for each sound. Like for the word 'rabbit' I wrote /r/, /æ/, /b/, /I/, /t/."'

«When I wanted to write 'lake' I remembered 'cake' which we had before. They have the same rhyme, so I spelled it like that.»

«The word 'bean' has the sound /i:/. This sound is spelled either with 'ee' or'ea'. I remembered that it is spelled with 'ea'.»

Many of the students who were average or good spellers explained that they used more than one way to spell the words and if one strategy did not help them, they easily shifted to another strategy. If a child stated that s/he did not know how the word was spelled, then the following was said, «Just try your best. Remember, I am just interested in finding out what helps you know how to spell the word.» These prompts were based upon the prompts used by Rittle-Johnson and Siegler (1999).

Table 1. Spelling strategies, definitions and examples from participants' answers.

\begin{tabular}{|c|c|c|}
\hline Spelling Strategy & Definition of the Strategy & $\begin{array}{l}\text { Example of subject's } \\
\text { answer }\end{array}$ \\
\hline Retrieval & $\begin{array}{l}\text { The immediate recall of an answer } \\
\text { previously stored in memory. Other } \\
\text { strategies are not used. Child shows no overt } \\
\text { signs of using another strategy. }\end{array}$ & $\begin{array}{l}\text { "That's easy. I just knew it" } \\
\text { "I learned that a long time } \\
\text { ago" }\end{array}$ \\
\hline Sounding out & $\begin{array}{l}\text { Using phonetic clues or sounds to spell all or } \\
\text { part of a word. }\end{array}$ & $\begin{array}{l}\text { "I sounded it out" } \\
\text { "I spelled it out" }\end{array}$ \\
\hline Analogy & Using another word to assist in spelling & $\begin{array}{l}\text { "I thought of the word cake } \\
\text { (for lake)" }\end{array}$ \\
\hline Rule use & $\begin{array}{l}\text { Referring to specific rules that one has } \\
\text { learned to spell a word }\end{array}$ & 'ea' has the sound /i:/. \\
\hline Syllabification & $\begin{array}{l}\text { Dividing a word into syllables or what a } \\
\text { child thinks are the words syllables, and } \\
\text { spelling the parts }\end{array}$ & $\begin{array}{l}\text { "I broke it into pieces" } \\
\text { "I did this, /rain//coat//s/" }\end{array}$ \\
\hline Visual memory & Using a mental image of the word to spell it & $\begin{array}{l}\text { "I thought of the window of } \\
\text { my room and spelled it." }\end{array}$ \\
\hline Visual checking & $\begin{array}{l}\text { Writing the word, looking at it, and } \\
\text { correcting it, if necessary. }\end{array}$ & $\begin{array}{l}\text { Observed behavior, then } \\
\text { asked participant }\end{array}$ \\
\hline
\end{tabular}




\section{RESUlts}

The first set of results reported indicates the frequency of the spelling strategies used by the children. The second set of results shows the differences between participants who were above average, average, or low ability spellers.

Among the different strategies used for spelling words, retrieval was the strategy most frequently used by participants to spell a word or as a way to spell part of a word. Students used many different types of strategies, as seen in Table 2. These included sounding out (including letter naming and modified sounding out), analogy, rule use, visual memory and checking, and syllabification. The most commonly used strategies after retrieval were sounding out and analogy.

Table 2. Total number and percentages of strategy use by children.

\begin{tabular}{lcc}
\hline Strategies & Number of use & Percentage of use \\
\hline Retrieval & 124 & 46.7 \\
Sounding out & 98 & 34.0 \\
Analogy & 36 & 9.0 \\
Rule use & 18 & 6.4 \\
Syllabification & 9 & 2.3 \\
Visual checking & 4 & 0.70 \\
Visual memory & 0 & 0 \\
\hline
\end{tabular}

Considering the use of strategies in good, average, and poor spellers, it was concluded that $78 \%$ of the good spellers, $60 \%$ of the average, and only $26 \%$ of the poor spellers used the most common strategies for spelling words. Sounding out and visual strategies were used most frequently by poor spellers and least frequently by good spellers. Conversely, analogy and syllabification were used most frequently by good spellers and least often by poor spellers.

There was a combination of strategies and changes from one strategy to another seen more in good and average spellers and less in poor spellers. In addition to the difference in the percentages of strategy use in the three levels, there was also a difference in the type and quality of the strategies used among them.

\section{Discussion}

How do children spell words? This single, simple question requires a complex analysis of the cognitive processes used as children endeavor to spell words correctly. The goal of this study was to investigate this simple question to find out about the development of spelling skills, strategy use and utility of Siegler's spelling development model to see whether children develop multiple strategies while spelling or not.

As was expected, children spelled words differently based upon their strategy use and spelling ability level. Average and above average spellers wrote words correctly more often 
than children who were poor spellers. The retrieval strategy, the instant recall of an answer, was used a lot by children but more frequently by good and average spellers. Poor spellers used retrieval the least. More to the heart of this study, children did use many strategies to spell words. The repertoire used by children included more than one or two strategies for spelling. Sounding out and analogy were used most often, while rule use, syllabification and visual checking were used less frequently. Good and average spellers used multiple strategies more to help them spell the words, but they used the most strategies on difficult words.

As established by Siegler (2000) in his spelling development model, there is variability in strategy use through the spelling process. This study clearly supports this assumption. Children did use multiple strategies to spell words. Variability in strategy use was observed in all types of spellers but more in good and average spellers. This is in line with the findings of multiple strategy use in other areas of development of problem solving (Bjorklund, 2001; Chen \& Siegler, 2000; Thelen \& Ulrich, 1991).

As stated above, poor, average, and good spellers differ in strategy use qualitatively and quantitatively. In terms of quantity, participants in all spelling ability levels used multiple strategies to spell. Good and average spellers used retrieval more often than the other group. In terms of quality, good spellers used complex strategies more often. For example, analogy and syllabification were used most often by good spellers. Sounding out and visual checking were the preferred strategy of poor spellers. The reason was that this strategy requires less manipulation of a word.

Kamhi and Hinton (2000) speculated that the differences between good and poor spellers may be due to the poor spellers' use of visual strategies more often than good spellers. They stated that reliance upon visual strategies was due to poor phonological skills. In the present study, visual checking, a simpler strategy (compared to syllabification), was used by poor spellers. Poor spellers were less likely to rely upon this visual strategy than they were to rely upon the strategies which would utilize phonological skills, meaning, and sounding out.

\section{Conclusion}

In general this study helped to support the spelling development model established by Siegler (2000) but also aimed at showing the frequency of strategy use among EFL children. The most interesting results were the differences in strategy use among the children with different spelling abilities. Children who are better spellers use more strategies than poor spellers. A combination in strategy use is also viewed more in good spellers.

Syllabification and analogy are strategies utilized more by children who are good spellers and sounding out and visual checking are mostly used by poor spellers. Retrieval is used by all children with different spelling abilities but again more by good and average spellers.

Spelling instruction should be based upon good research, as O'Sullivan (2000) suggests. Helping the poor spellers learn to be more adaptive in strategy choice as well as thinking about the parts (or syllables) of the word to help them use multiple strategies more effectively could improve instruction. 


\section{REFERENCES}

Beers, J. W. (1980). "Developmental strategies of spelling competence in primary school children", in E. H. Henderson and J. W. Beers (eds.), Developmental and Cognitive Aspects of Learning to Spell: A Reflection of Word Knowledge. Newark, DE: International Reading Association, 36-45.

Bjorklund, D. F. and Rosenblum, K. E. (2001). "Children's use of multiple and variable addition strategies in a game context", in Developmental Science, 4, 2:184-194.

Chen, Z. and Siegler, R. S. (2000). "Across the great divide: bridging the gap between understanding of toddler's and older children's thinking", in Monographs of the Society for Research in Child Development, 65, No 2.

Crowley, K., Shrager, J. and Siegler, R. S. (1997). "Strategy discovery as a competitive negotiation between metacognitive and associative mechanisms", in Developmental Review, 17, 4: 462489.

Crowley, K. and Siegler, R. S. (1999). "Explanation and generalization in young children's strategy learning", in Child Development» 70, 2:304-316.

Ehri, L. C. (1987). "Learning to read and spell words", in Journal of Reading Behavior, 19, 5-31.

Ellis, A. W. (1993). Reading, Writing and Dyslexia: A Cognitive Analysis. (2nd ed.). Hove: Lawrence Erlbaum.

Graham, S. (1999). "Handwriting and spelling instruction for students with learning disabilities: A review", in Learning Disabilities Quarterly, 22, 2: 78-98.

Graham, S. (2000). "Should the natural learning approach replace spelling instruction?", in Journal of Educational Psychology, 92, 2: 235-247.

Greaney, K., Tunmer, W. E. and Chapman, J. W. (1997). "Effects of rime-based orthographic analogy training on the word recognition skills of children with reading disability", in Journal of Educational Psychology, 89, 4: 645-651.

Kamhi, A. G. and Hinton, L. N. (2000). "Explaining individual differences in spelling ability", in Topics in Language Disorders, 20, 3:37-49.

Moats, L. (1995). Spelling: Development, Disability, and Instruction. Baltimore, MD: York Press.

O'Sullivan, O. (2000). "Understanding spelling", in Reading, 34, 1: 9-16.

Rittle-Johnson, B. and Siegler, R. S. (1999). "Learning to spell: Variability, choice, and change in children's strategy use" in Child Development, 70, 2: 332-348.

Schlagal, B. (2001). "Traditional, developmental, structured language approaches to spelling: Review and recommendations", in Annals of Dyslexia, 51,147-176.

Shrager, J. and Siegler, R. S. (1998). "SCADS: A model of children's strategy choices and strategy discoveries" in Psychological Science, 9, 5: 405-422.

Siegler, R. S. (1989). "How domain-general and domain-specific knowledge interact to produce strategy choices", in Merrill-Palmer Quarterly, 35, 1: 1-26.

Siegler, R. S. (1995). "How does change occur: A microgenetic study of number conservation", in Cognitive Psychology, 28, 3: 225-273.

Siegler, R. S. (1996). Emerging Minds: The Process of Change in Children's Thinking. New York: Oxford University Press.

Siegler, R. S. (2000). "The rebirth of children's learning”, in Child Development, 7, 1: 26-35.

Siegler, R. S. (2002). "Microgenetic studies of self-explanation", in N. Granott and J. Parziale (eds.), Microdevelopment: Transition Processes in Development and Learning: Cambridge Studies in Cognitive Perceptual Development. New York: Cambridge University Press, 3158. 
Siegler, R. S. and Crowley, K. (1991). "The Microgenetic method: A direct means for studying cognitive development", in American Psychologist, 46, 6: 606-620.

Simon, D. and Simon, H. (1973). "Alternative uses of phonemic information in spelling", in Review of Educational Research, 43, 1:115-137.

Stanovich, K.E. and Cunningham, A.E. (1993). "Where does knowledge come from? Specific association between print exposure and information acquisition", in Journal of Educational Psychology, 85, 2: 211-229.

Thelen, E. and Ulrich, B. D. (1991). "Hidden skills", in Monographs of the Society for Research in Child Development, 56(Series No 223).

Thompson, D. R. and Siegler, R. S. (2000). "Buy low, sell high: The development of an informal theory of economics", in Child Development, 71, 3: 660-677. 